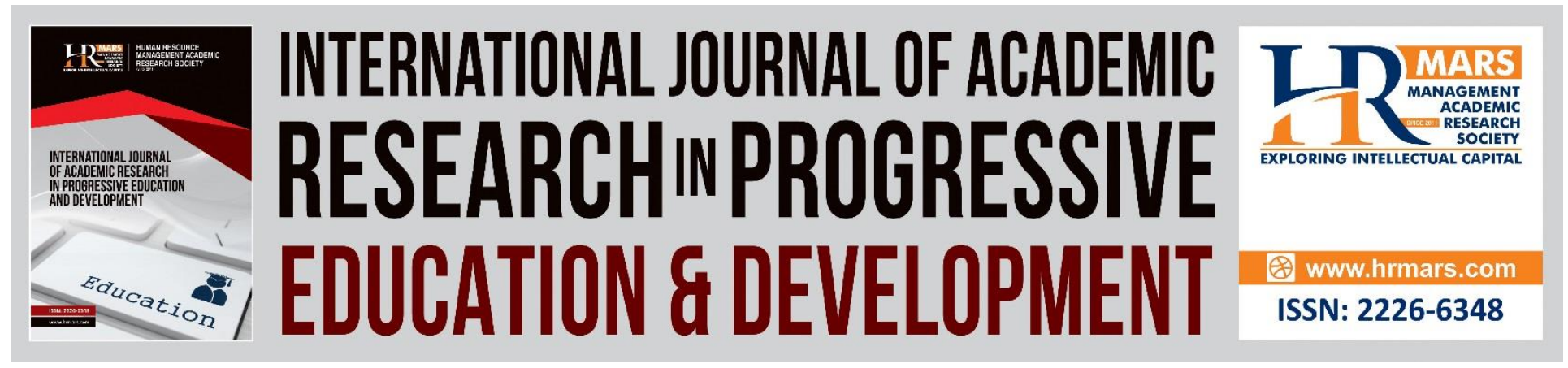

\title{
An Evaluation of the Technical Vocational Livelihood Track in Public Senior High Schools in the Division of Batangas: Basis for an Enhancement Program
}

Fermo G. Ramos

To Link this Article: http://dx.doi.org/10.6007/IJARPED/v10-i2/10269

DOI:10.6007/IJARPED/v10-i2/10269

Received: 10 April 2021, Revised: 12 May 2021, Accepted: 22 May 2021

Published Online: 25 June 2021

In-Text Citation: (Ramos, 2021)

To Cite this Article: Ramos, F. G. (2021). An Evaluation of the Technical Vocational Livelihood Track in Public Senior High Schools in the Division of Batangas: Basis for an Enhancement Program. International Journal of Academic Research in Progressive Education and Development, 10(2), 877-900.

Copyright: (C) 2021 The Author(s)

Published by Human Resource Management Academic Research Society (www.hrmars.com)

This article is published under the Creative Commons Attribution (CC BY 4.0) license. Anyone may reproduce, distribute, translate and create derivative works of this article (for both commercial and non-commercial purposes), subject to full attribution to the original publication and authors. The full terms of this license may be seen at: http://creativecommons.org/licences/by/4.0/legalcode

Vol. 10(2) 2021, Pg. 877 - 900

http://hrmars.com/index.php/pages/detail/IJARPED

JOURNAL HOMEPAGE

Full Terms \& Conditions of access and use can be found at http://hrmars.com/index.php/pages/detail/publication-ethics 


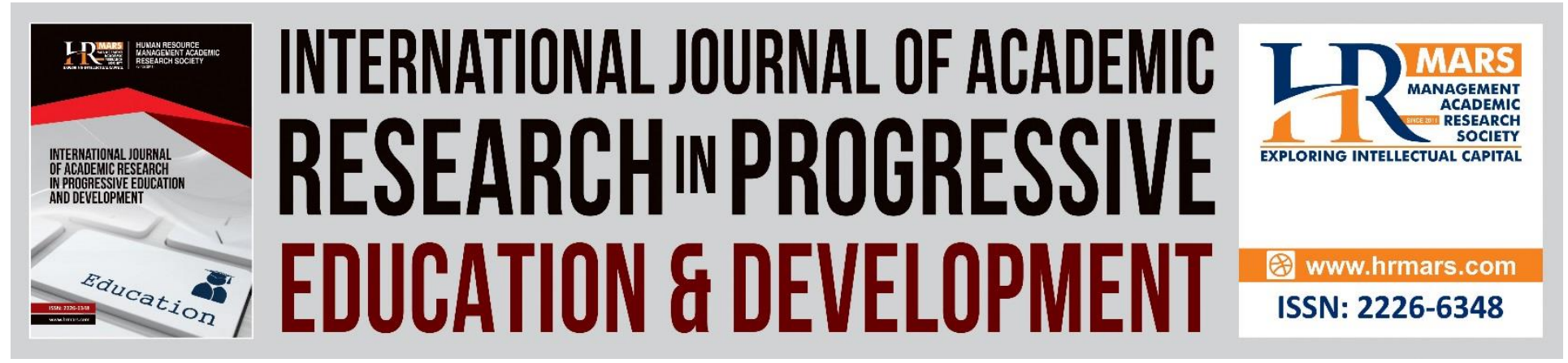

\title{
An Evaluation of the Technical Vocational Livelihood Track in Public Senior High Schools in the Division of Batangas: Basis for an Enhancement Program
}

\author{
Fermo G. Ramos, PhD \\ Graduate School and Open Learning College, Cavite State University Cavite, Philippines \\ Email: ramosfermoii@gmail.com
}

\begin{abstract}
The establishment of the Senior High School program in the Philippines has put technical vocational education in the limelight. The offering of techvoc education in various schools is aimed at equipping the students with the skills and knowledge needed should they choose middle-level employment after graduation. This study aims to serve as a guide to school administrators for them to effectively implement the program despite the challenges. This study was conducted to evaluate the implementation of the Technical Vocational Livelihood Track in public senior high schools in the Division of Batangas in terms of level of adequacy of inputs, level of compliance with the standards of Department of Education, extent of implementation of processes, and level of satisfaction with outputs. The descriptive-evaluative research design was used in the study. The participants were 36 school heads, 119 TVL teachers, and 375 students of public senior high schools. A self-made survey questionnaire was utilized but interviews and documentary analysis were also conducted to identify the problems met in the implementation. Spearman Rank was used to determine the extent of relationships between and among the variables of the study. The Kruskall Wallis $H$ Test was used to determine the extent of difference among the assessments of the three groups of participants.

Inputs in the TVL track was adequate while compliance to DepEd standards was found to be of great extent. The extent of implementation of the processes was found to be very high extent while the level of satisfaction was rated as very satisfied. I Significant relationship was found between level of satisfaction and adequacy of inputs, level of satisfaction and compliance with standards, and level of satisfaction and extent of implementation. In addition, significant difference was found among the evaluation made by the three participants on the adequacy of input, level of compliance, extent of implementation, and level of satisfaction. To further evaluate the effectiveness of the TVL track, the study suggests that future researches concerning employability of techvoc graduates may be conducted.
\end{abstract}


Keywords: Technical Vocational Livelihood Track, Senior High School, Program Evaluation

\section{Introduction}

Quality education has been the major thrust of Philippine Education. In its truest sense, quality education means upgrading educational standards geared towards attainment of educational excellence. Educational excellence is manifested when there is a highly effective curriculum, adequate material resources, and efficient and efficacious school heads and teachers (Alferez \& Palmes, 2012).

To reform the education system in the Philippines, the Enhanced Basic Education Act (RA 10533) was signed into a law in 2013. RA 10533 was crafted to improve the country's education system through a strengthened curriculum. A key feature of this law is the Senior High School program that added Grade 11 and Grade 12 making compulsory pre-college education 13 years. The SHS program was rolled out in 2016 , which seeks to produce students that are holistically developed, equipped with the 21st century skills and prepared for the future, regardless of their chosen paths, may it be higher education, attainment of middle-level skills, employment or entrepreneurship. The SHS includes two years of specialized upper secondary education. It is one where student has the option to choose a specialization based on their aptitude, interests, and school capacity. The students' choice of career track will define the content of the subjects they will have to take which will fall under either the core curriculum or specific tracks. Under the present model, the student can choose among four tracks, namely: Academic, TechnicalVocational Livelihood, Sports, and Arts and Design.

The Technical-Vocational Livelihood track is composed of specializations in the agriculture and fishery sectors, garments, tourism, health, processed food and beverages, social and community development service, automotive and land transport, construction, electronics, furniture and fixture, metal and engineering, utilities, and information and communications technologies sectors (DepEd Order No. 21, series 2019). The TVL track is the aspect of the Senior High School program that exposes the learner to acquisition of demonstrable skills/competencies and values that could be transformed into economic benefits (Brillantes et.al, 2019). It intends to provide students with technical vocational training and skills and academic know-how to prepare them for the needs of the community and the global workplace through highly trained competent teachers.

In school year 2017-2018 there was a total of 1,025,907 students who took up TVL track in 11,087 senior high schools in the country (PIDS, 2019). In the Division of Batangas Province, the TVL track is second to the Academic track in terms of number of enrollees. In fact, there was a total of 10, 376 students taking up TVL specializations in school year 2019-2020 in forty-five public senior high schools around the province (Planning Office, Division of Batangas).

A recent study published by the Philippine Institute for Development Studies (PIDS, 2019) presented a process evaluation determining the extent of implementation of the SHS program and identifying the best practices, and issues and areas for improvement. It was revealed in the study that the implementation of the TVL track is hampered by the issues in curriculum delivery, work immersion, students' unpreparedness, problems with partnership, inadequacy of competent teachers, and inadequate material resources. 
Our society is facing an unprecedented crisis due to threats of a global health pandemic. At the beginning of 2020, an unprecedented blow due to COVID-19 has affected the health of hundreds of thousands of people. It continues to claim lives of people in many parts of the world. Perhaps this is the biggest crisis of the $21^{\text {st }}$ Century, with a high number of recorded deaths. As a result, there are widespread school closures in many countries. Education and training systems around the world have started to respond to the situation. Under the circumstances, TVET, an important subset of education and which takes place in secondary, post-secondary and tertiary levels, including work-based learning, continuing training and professional development, cannot be a silent spectator.

Since the roll-out of the Senior High School program in the Division of Batangas, there has been no study made on assessing the implementation of the Technical Vocational Livelihood track. It is in the aforementioned rationale that the researcher finds it necessary to assess the status of the implementation of the TVL track so that whatever findings are made maybe utilized to improve the program in action planning, policy formation and development. This study will identify the gaps in the implementation of the technical vocational livelihood track specifically on the program's input, process, and output. Such gaps will serve as an eye-opener to school administration to take a closer look at the problems presented and provide long-term solutions. Ultimately, the students of the technical vocational track will benefit this study as they will be the direct recipients of any program enhancement including but not limited to provision of material resources and improved teaching and learning processes.

\section{Objectives of the Study}

The objectives of the study are: (1) to determine the profile of participant school heads, TVL teachers, and students, (2) identify the inputs in the implementation of the technical vocational livelihood track, (3) determine is the level of compliance of the schools to DepEd standards, (4) determine the processes involved in the technical vocational livelihood track and their extent of implementation, (5) determine the outputs of the technical vocational livelihood program and their level of satisfaction, (6) determine significant relationship between the variables of the study, (7) determine significant differences among the assessment made by the participants, and (8) identify the problems met in the implementation of the TVL track.

\section{Literature Review}

The Technical-Vocational Education and Training

It is the preparation of persons in the secondary level to enter upon employment in the area of occupation where students are trained and best suited (Castillo, 2012). On the other hand, technical education prepares individuals who have gone through the secondary high school level in the areas of trade, agriculture, fishery and other kinds of technology to enter upon employment in the areas they are trained and best suited. He emphasized that the concern of technical and vocational training relevant to the needs of the occupation whose primary purpose is employment.

Vocational Education and Training (VET) prepares trainees for jobs that are based on manual and practical activities, traditionally non-academic and totally related to a specific trade, occupation, or vocation. It is sometimes referred to as technical education as the trainee is 
directly develops expertise in particular groups of techniques in technology. As noted by Galvez (2009), vocational educations around the country believe trade schools are making strong come back because many businesses have a desperate need for skilled workers. Many of today's high school graduates and students are learning to be computer science professionals, chefs, graphic designers, mechanics, engineers, and so forth. While more and more students are entering to the workforce with a degree most lack the hands-on skills necessary to just jump right in without additional on-the-job -training.

Esguerra and Orbeta (2016) suggested that technical vocational education must make training continuously relevant to industry needs. There is a need for a continued review of curriculums and training regulations. There must be a mechanism for establishing or convening of industry councils for regular labor market signaling. TVET must address specific skill needs of roadmaps and important value chains. The TVI-industry linkages must be increased. Relevance of training should ultimately be measured by the employment rates of trainees.

Inputs in the Technical Vocational Livelihood track

\section{Curriculum}

Curriculum is the result of piecing together of a number of information including vision and mission statements of educational institutions. Objectives, contents, methods and assessment are the key elements of a curriculum (Salam, 2015). Historically, vocational programs have been designed as preparation for a single occupation (Cedefop, 2012). In the 21st century, however, those entering the labor market need not only immediate job skills but also a range of competencies enabling them to change jobs and careers throughout their working life. In addition, some vocational education pathways have been designed with the expectation that students can continue to post-secondary studies, even to university level. This shift from narrow occupational training to broader preparation for work or further education has increased the general subjects included in a vocational program (Chae \& Chung, 2009). Most secondary vocational programs include literacy and numeracy requirements. In addition to technical skills, many aims to develop the "soft" skills that employers want, such as an ability to work in teams, communicate with customers, and think critically. In Finland, for example, the core curriculum includes an understanding of other countries and cultures (Cedefop, 2012); the promotion of standards and sustainable development; the use of information technology; entrepreneurship; high-quality and customer-focused activity; consumer skills; and the management of occupational health and safety. Although vocational studies typically still receive more time in curricula than general subjects, there is enough attention to academics to ensure that students are ready for post-secondary education or can reach readiness with a few extra studies (Constant, Culbertson, Luoto, \& Vernez, 2012).

\section{Instructional Materials}

The study of Albarico et al. (2014) showed that the instructional materials helped to carry out the achievement of the BSE-TLE program by engaging students in interactive learning and considering the varied interest, abilities and maturity levels of the student. It is also revealed that there are available instructional materials for all areas in the TLE program and it is used appropriately in the corresponding subjects. On the other hand, the findings also imply that there 
is an inadequacy in the number of instructional resources as well as the number of the tools and equipment in relation to the number of students enrolled. And for this reason, students experienced buying their own materials which is supposedly provided by the school. The instructional tools, machines and equipment used in teaching TLE are not monitored and checked as well as if it is in good running condition. Thus, the result suggests that there is a need to review the instructional materials to suit the needs of the curriculum for the betterment of the course.

\section{Physical Facilities}

In the study of Salatan (2018) the adequacy of physical facilities: canteen and classroom are found to be very adequate, lighting, comfort rooms, study shed, working tables, and library spaces are rated as moderately available. Laboratory rooms, spacious shop and exhibit rooms are described as slightly adequate. Along the adequacy of laboratory facilities: diagram board is rated as very adequate. Washing area, faucet, preparation area, and storage cabinet are found to be moderately available and display cabinets is described as slightly adequate. Ike, Nwamuo, and Ojukwu, (2011) pointed out that there is the need for adequate facilities in technical college school workshops. He suggested that the only way of determining the level of facilities in the workshop is to check the tools, machines, resources and materials available in the workshop. Ike, Nwamuo and Ojukwu (2011) emphasized that entrepreneurial skills and sustainable technological development cannot be achieved if school workshops are in the midst of inadequate facilities and resources.

\section{Tools, Materials, and Equipment}

Along with the adequacy of tools and equipment under Home Economics, Bread and Pastry, Dressmaking and Commercial Cooking are rated as moderately adequate. While, Beauty Care is found to be slightly adequate and Wellness Massage is found to be inadequate. Along the adequacy of tools and equipment under Agri-fisheries is found to be slightly adequate. Along with the adequacy of tools and equipment under Industrial Arts, Shielded Metal and Welding is rated as slightly adequate while Consumer Electronics Servicing is described as inadequate. Along with the adequacy of tools and equipment under Information and Communication Technology is found to be slightly adequate. Along with the adequacy of Instructional materials: charts, curriculum guide, picture and laptop are found as moderately adequate, and the rest are rated as slightly adequate. The study of Edmond et al. (2016) showed that tools such as Eraser, Measuring Tape, Shovel, Cutlass, compass, tracing paper, Tracing pen, French curve, Theodolite, Profile Board, clutch pencil, drawing sheet, T-square, drawing board, set square, bevel, boat level, pointing trowel, mixer, jointer, hammer, saw, meter rule, lines and pipe, spirit level, square, plumb rule, laying trowel and straight can be used in teaching building technology in technical colleges.

\section{Work Environment}

Okorie, (2000) as cited by Castillo (2012) contended that the workshops, laboratories and the overall building technology environment must be adequately equipped so as to reflect the actual working environment beyond the classroom. He stated further that the school environment should expose students to the use of basic building equipment in a way that will 
lead students to acquire relevant knowledge and skills. He added that the skills being developed by students in training are necessarily limited by the availability of equipment and tools. A workshop where there are insufficient tools, the students will be grouped by the teachers during practical work so that each group will be given a set of few tools to practice with. It will be difficult for all the students in a particular group to acquire needed skills in their field. In such a workshop with insufficient tools, mostly in the case of grouping students during practical, it is observed that one person probably the group leader will be doing the practical for others as a result of insufficient tools.

According to Olabiyi et al., (2008) as cited by Ramos (2016) many educators are of the view that learning occurs best through participation. The uses of training facilities help teachers to direct the learning of their students instead of talking from higher platform to passive students, some of who might be asleep. Students, as we know, learn by discovery and the teacher cannot have in stock all that the child needs to know. The psychological relevance of individualized instruction also necessitates the use of various approaches to cover the different abilities and perceptions of students. Nothing else can help to achieve better diversification of lesson in the classroom than educationally certified training facilities and techniques.

\section{Program Objectives}

The study of Audu et al., (2013) discussed that the goals of TVE shall be to provide trained manpower in the applied sciences, technology and business particularly at craft (equivalent of high schools), advanced craft and technical levels; provide the technical knowledge and vocational skills necessary for agricultural, commercial and economic development; to give training and impart the necessary skills to individuals who shall be self-reliant economically. At all levels of the nation's educational system and for all known and existing school types, instructional facilities or teaching and learning materials are an indispensable factor in the attainment of the goals.

Uzoagulu (Umar and Ma'aji, 2010), warned that where the facilities, equipment and tools are not adequate and for use by the teeming number of TVE students acquisition of skills in technical training programs will suffer and will lead to the production of highly unskilled personnel who are unemployable and unproductive. Therefore, inadequate workshop facilities in TVE institutions deterred skill acquisition.

Compliance of Technical Vocational Track with DepEd standards

\section{Curriculum and Instruction}

The TVE curriculum as described utilizes competency-based education that aims to develop technical workers equipped with high behavioral and thinking competency concerning technical tasks (Salleh and Sulaiman, 2015). Likewise, teaching approaches play a vital role in delivering the curriculum. Students' interest and the varying demands of different learning and teaching styles may broaden the teachers' teaching styles and approaches. It may guide them in improving their attitude and behavior towards learning as well as their competencies (Yusof, Roddin and Awang, 2015). 


\section{Faculty Qualification in Technical Education}

Omekwe (2009) as cited by Ramos (2016) stressed that to effectively implement any education programme, adequate human and material resources must be available to the schools. In particular, a large enough number of trained teachers with different types of expertise (science, language, technology, etc.) must be recruited and posted to the schools as and when required. In addition, for effective management, academic staff must be complemented by nonacademic staff in proportionately adequate numbers.

Click (as cited by Castillo, 2012) believed that some beginning teachers or may be some leaders are at survival level. They just try to get through the difficulties of each day. Training can help them to move to new levels of effectiveness and can give them anew enthusiasm in carrying out jobs. Stress and burnout are problems that plague school heads and teachers for their work require a lot of emotional energy. Training can furnish some new tactics and strategies that minimize stress and decrease burnout.

Training people is more challenging than managing resources from one day to next. It helps to be useful and productive in their present jobs, competitive in their skills, talents and knowledge vis-à-vis their foreign counterparts (Tullao, as cited by Ramos, 2016). Training enhances the competencies and productivity of the people and empowers the organization to be competitive in the global market.

\section{Work Environment, Tools, Materials, and Equipment in Technical Education}

The major problem facing technical and vocational education includes inadequate quantities of equipment, machines, tools and instructional materials (Osuala as cited by Castillo, 2012). Carrying capacity can be in tertiary purchase of adequate equipment and facilities in our tertiary institutions. The development of capacity, potentials, self-actualization, appreciation and application of knowledge gained to solve practical problems in the fast technological changing society cannot be achieved, if equipment, teaching techniques and devices are not adapted to the demands of the technological and scientific age in which students have to live and function.

General considerations in connection with trade and industrial education programs include, but are not limited to the following: Corridor doors into laboratories and related classrooms s accommodate large items of equipment other than the machinery used for instruction. General and specific illumination in all area should be appropriate to the instructional/learning tasks of the specific program and over-all facility design to provide balanced lighting conditions (Castillo, 2012). Naelga and Blane (2017) pointed out the lack of learning materials, facilities and manpower are among the problems that teachers are facing in the implementation of $\mathrm{K}$ to 12 . The learning materials are not only delivered late or not on time, but the copies are limited; hence, the teachers have taken the initiative to spend their own money to photocopy the workbooks and manuals.

Processes in the Technical Vocational Livelihood track

According to Agrawal (2013), vocational education and training (VET) focuses on specific trades and imparts the practical skills that allow individuals to engage in a specific occupational activity. It also intends to provide employment opportunities to individuals and help in enhancing the productivity of firms. He also cited that vocational education and training is an indispensable instrument in improving labor mobility. Both adaptability and productivity contribute to 
enhancing firms' competitiveness and redressing labor market imbalances. It comprises all skill transfers, formal and informal, that are required to improve the productive activities of a society.

Consequently, partner industries are definitely after their operations and productions. Though, they accommodate trainees, they seldom give emphasis on how well the trainees would learn from them since most trainers lack interest in the future employment of their trainees. Therefore, the expected outcomes are not fully satisfied even after the training has ended. Also, lack of proper monitoring and evaluation by the institution of on-the-job training is missing. After the deployment of trainees, the practicum supervisors seemingly give little attention to feedbacks that can later be utilized as baseline data and information to make the TVE curriculum more responsive to needs of the labor market (Leong, 2011).

Outputs of the Technical Vocational Track

Outputs are the end-product of educational inputs and process those must be assessed based on objectives. Output is the product of educational input and process which must be assessed (Salam, 2015). The quality of assessment carried out to measure the output in schools has been a growing concern for educators. The main output of an educational system is the students and the attributes that the student may have developed throughout his education journey (Brillantes, Orbeta, Abrigo, Capones, \& Jovellanos, 2019). The attributes may pertain to the knowledge, skills, and attitudes developed including the intermediate final outcomes of the program. Intermediate outcomes pertain to high enrolment rates while final outcomes may include test scores, completion rates, drop-out rates, repetition rates, passing rates, TVL certification rates, and employment or entrepreneurship rates. There are certain attributes that students and graduates of technical-vocational education must possess (Bappah \& Medugu, 2013). These include basic literacy and numeracy, critical thinking, management skills, leadership skills, interpersonal attributes, information and technology skills, systems thinking, and work ethic.

\section{Problems in the Implementation of Technical Vocational Livelihood program}

Serumu (2014) identified the challenges of implementing TVET curriculum. These include inadequate and obsolete infrastructure and Equipment, inadequate capacity in the institutions for internal/peer quality assessment, weak support structure for students Industrial Work Experience Scheme (SIWES), Brain drain, human capital flight, high incidence of cultism, examination malpractice and social and academic vices, unstable academic calendar, staff shortages across board, unattractive conditions of service for teachers, inadequate funding of tertiary institutions, and inadequate collaboration between tertiary institutions and organized private sector.

Perez (2018) stressed that there are still problems which need to be addressed in the implementation of the technical vocational education in the Philippines. These include the lack of learning materials, facilities and equipment as well as space for classrooms. Based from the results, these problems did not drastically affect the perceived level of operational preparedness of the SHS program by various stakeholders- teachers, parents and students. This outcome may be linked to the interventions conducted by teachers, as prescribed in their trainings. Preparation of contextualized learning materials from existing ones and modification of class schedule (having morning and afternoon class sessions) are examples of these interventions. Gregorio (2016) 
Vol. 10, No. 2, 2021, E-ISSN: $2226-6348$ @ 2021 HRMARS

mentioned that the following are the foremost perceived problems by the TVL teachers in general secondary schools in teaching the subject are lack of teaching strategies, lack of trainings related to area of specialization, no capital investment and inadequacy of facilities and equipment.

\section{Methodology}

Research Design

This study utilized the descriptive-evaluative method of research. A descriptive-evaluative research is a type of descriptive research that is aimed at judging the goodness of an existing program. It is directed to whether or not a particular program has achieved its goals by valuing judgment in terms of effectiveness, desirability, or social validity (Cohen et al., 2007).

Participants of the study

The participants of this study were school heads, teachers, and students of selected public senior high schools in the Division of Batangas Province. A total of 36 school heads, 119 teachers, and 375 students participated in the study.

Sampling Technique

The researcher determined the sample size for school heads and teachers by using total enumeration. All thirty-six (36) public senior high school principals and one hundred nineteen (119) TVL teachers in the Division of Batangas province were participants in this study.

On the other hand, the researcher used Cochran formula in determining the sample size of student participants. From the calculation, only 375 students were involved in the study. Research Instruments

The researcher used a set of self-made questionnaire to solicit the perception of the participants on the TVL tracks' (1) adequacy of inputs, (2) level of compliance, (3) extent of implementation of the processes, and (4) level of satisfaction with the outputs. In this study, the researcher conducted interview in order to gather data on the (1) inputs to the TVL track, (2) processes in the TVL track, and (3) outputs in the TVL track. Also, interviews with participant teachers and school heads were conducted in order to determine the problems met in the implementation of the TVL track.

The researcher utilized documentary analysis to gather data on the processes TVL track by looking into various school documents like school physical facilities reports and school report cards. Also, documentary analysis was used to gather data on student performance, academic rating, and National Certificate level.

\section{Statistical Data Analysis}

To ensure a valid and reliable interpretation of the results, various statistical techniques were utilized. Frequency count, and percentage were used to determine demographic profile of teachers and school heads in public senior high schools in Batangas. They were also utilized to determine demographic profile of student participants in terms of age, sex, grade level, specialization, and National Certificate. Mean and standard deviation were used to evaluate the level of adequacy of inputs, level of compliance with standards, extent of implementation of processes, and level of satisfaction with the outputs. Spearman Rho correlation coefficient was used to test relationship between level of satisfaction and adequacy of inputs, level of satisfaction 
INTERNATIONAL JOURNAL OF ACADEMIC RESEARCH IN PROGRESSIVE EDUCATION AND DEVELOPMENT

Vol. 10, No. 2, 2021, E-ISSN: 2226-6348 @ 2021 HRMARS

and level of compliance, and level of satisfaction and extent of implementation. Kruskall Wallis $\mathrm{H}$ Test was used to determine significant difference among the evaluations made by the three of groups of participants;

Analysis and Discussion of Findings

Profile of school heads and TVL teachers

Table 1. Demographic profile of school heads and TVL teachers

\begin{tabular}{|c|c|c|c|c|}
\hline & \multicolumn{2}{|c|}{ HEADS } & \multicolumn{2}{|c|}{ TEACHERS } \\
\hline & FREQUENCY & $\begin{array}{c}\text { PERCENTA } \\
\text { GE } \\
\end{array}$ & $\begin{array}{c}\text { FREQUENC } \\
\mathbf{Y} \\
\end{array}$ & $\begin{array}{c}\text { PERCENT } \\
\text { AGE } \\
\end{array}$ \\
\hline \multicolumn{5}{|l|}{ Sex } \\
\hline Male & 12 & 33.3 & 63 & 52.9 \\
\hline Female & 24 & 66.7 & 56 & 47.1 \\
\hline \multicolumn{5}{|l|}{ Educational Attainment } \\
\hline BS Degree Holder & 2 & 5.6 & 62 & 52.1 \\
\hline BS with MA Units & & & 47 & 39.5 \\
\hline MA Degree Holder & 1 & 2.8 & 7 & 5.9 \\
\hline MA with Doctoral Units & 26 & 72.2 & 3 & 2.5 \\
\hline Doctoral Degree & 7 & 19.4 & 0 & \\
\hline \multicolumn{5}{|l|}{ Specialization } \\
\hline English & 12 & 33.3 & 4 & 3.4 \\
\hline Science & 14 & 38.9 & 3 & 2.5 \\
\hline Physics & 1 & 2.8 & & \\
\hline Math & 6 & 16.7 & & \\
\hline Social Studies & 2 & 5.6 & & \\
\hline TLE & 1 & 2.8 & 34 & 28.6 \\
\hline Industrial Arts & & & 39 & 32.8 \\
\hline Home Economics & & & 12 & 10.1 \\
\hline Computer & & & 24 & 20.2 \\
\hline Accountancy/Marketing & & & 3 & 2.5 \\
\hline \multicolumn{5}{|l|}{ Trainings Attended } \\
\hline None & 33 & 91.7 & & \\
\hline Home Economics & 2 & 5.6 & 51 & 42.9 \\
\hline ICT & 1 & 2.8 & 26 & 21.8 \\
\hline Industrial Arts & 0 & & 42 & 35.3 \\
\hline \multicolumn{5}{|l|}{ National Certificate } \\
\hline None & 35 & 97.2 & & \\
\hline $\mathrm{NCl}$ & & & 6 & 5.0 \\
\hline NCII & & & 42 & 35.3 \\
\hline
\end{tabular}


Vol. 10, No. 2, 2021, E-ISSN: 2226-6348 @ 2021 HRMARS

\begin{tabular}{ccccc}
\hline NC III & 1 & 2.8 & 65 & 54.6 \\
NC IV & & & 6 & 5.0 \\
\hline Trainer's Methodology & & & & \\
\hline None & 35 & 97.2 & 0 & \\
TM I & 1 & 2.8 & 115 & 96.6 \\
TM II & 0 & & 4 & 3.4 \\
\hline
\end{tabular}

The results in Table 1 indicate that there were 12 male school heads (33.3\%) and 24 female school heads (66.7\%) who completed the instruments. The table also shows that there a total of 63 male TVL teachers (52.9\%) and 56 female TVL teachers (47.1\%) who completed the instruments.

The vast majority of school heads held Master's Degree with units in Doctorate studies $(72.2 \%)$ at the time of the study. While the majority of teacher-participants were BS Degree holders $(52.1 \%)$, followed by those with a BS degree with Master's Units (39.5\%). This implies that the school heads and faculty of TVL track in public senior high schools have a high level of education, which makes them highly qualified human resources. According to Cabahug (2015), a higher level of education is a manifestation that school leaders and teachers are highly driven and motivated individuals.

As to specialization $97 \%$ of school heads specialized in academic subjects. Only 1 school head had specialization in TVL. On the other hand, $32.8 \%$ of the teachers specialized in Industrial Arts education, 28.6\% in General TLE, 20.2\% in Computer Education, 10 \% in Home Economics, and $2.5 \%$ in Accountancy. There was a total of 7 teachers who specialized in Academic subjects. The findings on teachers' specialization contradict Cabahug's (2015) finding that majority of teachers handling TVL subjects do not specialize in TVL.

In terms of trainings attended The results indicate that majority of the school heads have not attended any training related to TVL education (91.7\%). This may be attributed to the fact that most of them specialized in academic subjects. On the other hand, $42.9 \%$ of the teachers had training in Home Economics, 35.3\% in Industrial Arts, and $21.8 \%$ in ICT. The results on teachers show that the teachers have the training required to teach TVL. According to Alferez and Palmes (2012), the success of an educational program is influenced by the length of the exposure of a person and his personal and professional attributes to a certain job or situation. The table also shows that only 1 school head had National Certificate. Among the teachers, 54.6\% had National Certificate III, $35.3 \%$ had National Certificate II, 5\% had National Certificate IV, and $5 \%$ had National Certificate I. These results imply that the teachers have more knowledge and deeper command on complex skills. Further, among the TVL teachers, $96.6 \%$ had TM level I, while $3.4 \%$ had TM level II. The results indicate that the vast majority of the TVL teachers are trained in the pedagogies technical-vocational training, which includes Planning Training Sessions, Managing Training Facilities, Supervising Work-based Learning, Utilizing Electronic Media, Facilitating Learning Sessions, and Conducting Competency Assessments (TESDA, 2018). Moreover, this means that teachers are competent enough to teach in the TVL track as prescribed under DepEd Order No. 3, s. 2016 on the guidelines for hiring teachers in the TVL track. 
INTERNATIONAL JOURNAL OF ACADEMIC RESEARCH IN PROGRESSIVE EDUCATION AND DEVELOPMENT

Vol. 10, No. 2, 2021, E-ISSN: 2226-6348 @ 2021 HRMARS

Profile of Students

Table 2. Demographic profile of students

\begin{tabular}{clcc}
\hline & & FREQUENCY & PERCENTAGE \\
\hline Sex & Male & & \\
& Female & 157 & 41.9 \\
& & 218 & 58.1 \\
\hline Grade Level & Grade 11 & & \\
\hline & Grade 12 & 154 & 41.1 \\
\hline Specialization & & 221 & 58.9 \\
\hline & Home Economics & 213 & \\
& ICT & 87 & 23.8 \\
& Industrial Arts & 70 & 18.7 \\
& Agri-Fishery & 5 & 1.3 \\
\hline National Certificate & & 17.1 \\
& None & 64 & 8.0 \\
& NCI & 30 & 62.1 \\
& NC II & 233 & 12.8 \\
\hline
\end{tabular}

The results in Table 2 indicate that there were 218 (58.1\%) female students and 157 (41.9\%) male students who completed the instruments. Grade 12 students comprise $58.9 \%$ of the participants while $41.1 \%$ were from Grade 11 . Majority of the students specialized in Home Economics strand (56.8\%). majority of the students had National Certificate II (62.1\%). Noticeably, only $1.3 \%$ or 5 individuals among the respondents have specialization in Agriculture and Fishery Arts. This result implies that only few of the SHS students have interest in the field of agriculture. 
INTERNATIONAL JOURNAL OF ACADEMIC RESEARCH IN PROGRESSIVE EDUCATION AND DEVELOPMENT

Vol. 10, No. 2, 2021, E-ISSN: 2226-6348 @ 2021 HRMARS

Inputs in the implementation of the Technical-Vocational Livelihood track and their level of adequacy.

Table 3. Mean of participants' evaluation of level of adequacy of input

\begin{tabular}{cccccc}
\hline INPUTS & $\begin{array}{c}\text { SCHOOL } \\
\text { HEAD }\end{array}$ & $\begin{array}{c}\text { TEACHE } \\
\text { R }\end{array}$ & $\begin{array}{c}\text { STU- } \\
\text { DENT }\end{array}$ & $\begin{array}{c}\text { COM- } \\
\text { BINED }\end{array}$ & $\begin{array}{c}\text { LEVEL } \\
\text { OF } \\
\text { ADEQUACY }\end{array}$ \\
\hline $\begin{array}{c}\text { Administrators } \\
\text { Students }\end{array}$ & 3.53 & 3.67 & 3.53 & 3.56 & VA \\
$\begin{array}{c}\text { Physical Facilities and } \\
\text { Laboratories }\end{array}$ & 3.37 & 3.24 & 3.16 & 3.18 & $\mathrm{~A}$ \\
$\begin{array}{c}\text { Tools, Materials and } \\
\text { Equipment }\end{array}$ & 3.28 & 3.07 & 2.75 & 2.86 & $\mathrm{~A}$ \\
Instructional Materials & 3.37 & 2.96 & 2.57 & 2.71 & $\mathrm{~A}$ \\
$\begin{array}{c}\text { Curriculum } \\
\text { Program Objectives }\end{array}$ & 3.43 & 3.37 & 3.16 & 3.23 & $\mathrm{~A}$ \\
Fiscal Resources \\
Linkages
\end{tabular}

Table 3 shows the participant's evaluation of the TVL track in terms of adequacy input. It can be gleaned from the findings that the adequacy of administrators and teachers as assessed by school heads, teachers, and students was found to be very adequate. The result implies that the technical-vocational track in the Division of Batangas has an adequate pool of administrators and teachers who are more qualified to implement the program. This is supported by the study of (Kong, 2017) which posited that schools offering TVL specializations have teachers who are very competent and qualified to teach the subjects assigned them.

The table also reveals that there was a low evaluation of the TVL's input in terms of physical facilities, fiscal resources, and instructional materials. Although these items were rated as Adequate, the mean ratings obtained were significantly lower than the rest of the inputs. This 
Vol. 10, No. 2, 2021, E-ISSN: 2226-6348 @ 2021 HRMARS

result implies that school administrators have to take a closer look at these components if they aim a more successful implementation of the program.

Level of compliance with DepEd standards of inputs

Table 4 shows the results of the participants' evaluation of the TVL track in terms of compliance to DepEd standards. As shown in the table, faculty qualification obtained the highest combined mean of 3.48 interpreted as very adequate. This implies that TVL teachers in the Division of Batangas province possess the necessary qualifications for teaching. This is supported by the study of (Kong, 2017) which posited that schools offering TVL specializations have teachers who are very competent and qualified to teach the subjects assigned them.

Table 4. Mean of participants' evaluation of level of compliance with DepEd standards

\begin{tabular}{cccccc}
\hline STANDARDS & $\begin{array}{c}\text { SCHOOL } \\
\text { HEAD }\end{array}$ & TEACHER & $\begin{array}{c}\text { STU- } \\
\text { DENT }\end{array}$ & $\begin{array}{c}\text { COM- } \\
\text { BINED }\end{array}$ & $\begin{array}{c}\text { LEVEL } \\
\text { OF } \\
\text { COMPLIANCE }\end{array}$ \\
\hline $\begin{array}{c}\text { Curriculum and } \\
\text { Instruction }\end{array}$ & 3.53 & 3.54 & 3.31 & 3.38 & VGE \\
$\begin{array}{c}\text { Faculty Qualification } \\
\text { Material Resources }\end{array}$ & 3.54 & 3.64 & 3.42 & 3.48 & VGE \\
Work Environment & 3.33 & 3.07 & 3.00 & 3.04 & GE \\
\hline TOTAL & 3.43 & 3.21 & 2.85 & 2.96 & GE \\
\hline
\end{tabular}

\begin{tabular}{cll}
\hline Legend: Scale & $\begin{array}{l}\text { Range of } \\
\text { Means }\end{array}$ & $\begin{array}{l}\text { Verbal Interpretation } \\
4\end{array}$ \\
& $3.25-$ & (VGE) Very Great Extent \\
& 4.00 & \\
3 & $2.50-$ & (GE) Great Extent \\
& 3.24 & \\
2 & $1.75-$ & (SE) Some Extent \\
& 2.49 & \\
1 & $1.00-$ & (LE) Least Extent \\
& 1.74 &
\end{tabular}

Apparently, the participants have varying assessments on compliance of material resources. Although the participants have varying assessments, it is nevertheless significant that compliance in terms of material resources is low. This supports the findings of Brillantes (2019) that there exists an inadequacy of facilities in the senior high school program due to procurement issues in the Department of Education. The availability of school facilities such as classroom technology and basic equipment is significantly related to student outcomes, which include performance and positive attitudes (Sabit, 2019). Educators and administrators are challenged to optimize the learning environment through its school facilities to ensure a meaningful learning process (Jaminal, 2019).

Table 4 also shows the data on the compliance of senior high schools in terms of work environment. It can be seen that school heads rated the compliance as very great extent with an 
Vol. 10, No. 2, 2021, E-ISSN: 2226-6348 @ 2021 HRMARS

over-all mean of 3.43, while teachers and student participants rated it as great extent only with overall means of 3.21 and 2.85 , respectively. For school heads, ranked first among the indicators is the consideration of water supply. This implies the school heads' awareness of their crucial role in the school processes and mechanisms, especially in facilitating the provisions for physical infrastructure (DepEd Order No. 21, 2019). On the other hand, the highest mean for both teachers and students is on the adequacy of fire alarm systems with mean of 3.47 and 3.28, respectively interpreted as very great extent. This is attributed to the fact that senior high school buildings around the country have at least two sets of fire alarms in each floor (Brillantes, Orbeta, Abrigo, Capones, \& Jovellanos, 2019).

The processes involved in the Technical-Vocational Livelihood track and their extent of implementation.

Table 5. Mean of participants' evaluation of extent of implementation

\begin{tabular}{|c|c|c|c|c|c|c|}
\hline \multicolumn{2}{|c|}{ PROCESSES } & $\begin{array}{l}\text { SCHOO } \\
\text { L HEAD }\end{array}$ & $\begin{array}{c}\text { TEACH } \\
\text { ER }\end{array}$ & $\begin{array}{l}\text { STU- } \\
\text { DENT }\end{array}$ & $\begin{array}{l}\text { COM- } \\
\text { BINED }\end{array}$ & $\begin{array}{c}\text { EXTENT } \\
\text { OF } \\
\text { IMPLEM } \\
\text { ENTATIO } \\
\mathbf{N}\end{array}$ \\
\hline $\begin{array}{r}\text { Curric } \\
\text { Inst } \\
\text { Teaching } \\
\text { meth }\end{array}$ & $\begin{array}{l}\text { ulum and } \\
\text { ruction } \\
\text { s strategies/ } \\
\text { odologies }\end{array}$ & 3.51 & 3.51 & 3.45 & 3.46 & VHE \\
\hline \multicolumn{2}{|c|}{ Classroom Management } & 3.43 & 3.66 & 3.36 & 3.43 & VHE \\
\hline $\begin{array}{r}\text { Assess } \\
\text { Eva }\end{array}$ & \multicolumn{5}{|c|}{ Assessment and } & VHE \\
\hline \multirow{2}{*}{\multicolumn{2}{|c|}{ Development }} & & & & & HE \\
\hline & & 3.48 & 3.53 & 3.25 & 3.33 & VHE \\
\hline Legend: Scale & $\begin{array}{l}\text { Range of } \\
\text { Means }\end{array}$ & \multicolumn{5}{|c|}{ Verbal Interpretation } \\
\hline 4 & $3.25-4.00$ & \multicolumn{5}{|c|}{ (VHE) Very High Extent } \\
\hline 3 & $2.50-3.24$ & \multicolumn{5}{|c|}{ (HE) High Extent } \\
\hline 2 & $1.75-2.49$ & \multicolumn{5}{|c|}{ (ME) Moderate Extent } \\
\hline 1 & $1.00-1.74$ & \multicolumn{5}{|c|}{ (LE) Low Extent } \\
\hline
\end{tabular}

Table 5 reveals that curriculum and instruction is implemented to very high extent. A mean of 3.51 was obtained for both administrators and teachers, and 3.43 for the students. This suggests that the teachers of the TVL track are highly competent individuals who are equipped 
with the necessary competencies. These findings support the study of Goodwin et al. (2017), which posited that teachers of Techvoc education have more knowledge and deeper command on complex skills.

The table also shows the extent of teaching strategies and methodologies as a process in the TVL track. The results revealed that all groups of participants rated teaching strategies and methodologies as very high extent with an overall mean of 3.58 by the school heads, 3.64 by the teachers, and 3.43 by the students. This implies that there is a high level of implementation and use of varied teaching methodologies by the TVL teachers in the division of Batangas. Further, the table also shows that student participants made a relatively low assessment of infrastructure development with means ranging from 2.60 as least and 3.09 as the highest all interpreted as High Extent only. This implies that students believed that there was minimal implementation of infrastructure development in the division of Batangas.

Apparently, all participants rated infrastructure development as to high extent with a mean of 3.00. This result may be implied that students have very little opportunity to enhance their learning due to the inadequacy of learning materials like computers, canteen spaces, and drinking and washing facilities. This result supports the finding of Limon (2016) that these kinds of facilities and infrastructure are not always available in public schools.

The outputs of the TVL track and level of satisfaction by school heads, teachers, and students Table 6. Mean of participants' evaluation of level of satisfaction with outputs

\begin{tabular}{|c|c|c|c|c|c|c|}
\hline \multicolumn{2}{|c|}{ OUTPUTS } & $\begin{array}{l}\text { SCHOO } \\
\text { L HEAD }\end{array}$ & $\begin{array}{c}\text { TEACHE } \\
\text { R }\end{array}$ & $\begin{array}{l}\text { STU- } \\
\text { DENT }\end{array}$ & $\begin{array}{l}\text { COM- } \\
\text { BINED }\end{array}$ & $\begin{array}{c}\text { LEVEL } \\
\text { OF } \\
\text { SATISFAC } \\
\text { TION }\end{array}$ \\
\hline \multicolumn{2}{|c|}{ Student's Knowledge } & 3.35 & 3.45 & 3.28 & 3.32 & VS \\
\hline \multicolumn{2}{|c|}{ Student's Skills } & 3.24 & 3.44 & 3.21 & 3.27 & VS \\
\hline \multicolumn{2}{|c|}{ Student's Attitude } & 3.31 & 3.42 & 3.25 & 3.29 & VS \\
\hline & TOTAL & 3.30 & 3.44 & 3.25 & 3.29 & VS \\
\hline Legend: Scale & $\begin{array}{l}\text { Range of } \\
\text { Means }\end{array}$ & \multicolumn{3}{|c|}{ Verbal Interpretation } & & \\
\hline 4 & $3.25-4.00$ & \multicolumn{3}{|c|}{ (VS) Very Satisfied } & & \\
\hline 3 & $2.50-3.24$ & \multicolumn{3}{|c|}{ (S) Satisfied } & & \\
\hline 2 & $1.75-2.49$ & \multicolumn{3}{|c|}{ (RS) Rarely Satisfied } & & \\
\hline 1 & $1.00-1.74$ & \multicolumn{3}{|c|}{ (NS) Not Satisfied } & & \\
\hline
\end{tabular}

The level of satisfaction with student performance in terms of knowledge is shown in Table 6. As shown in the table, all participants were all very satisfied with the students' acquisition of knowledge relative to the implementation of TVL track in the division of Batangas. This means that students, as an output of the TVL, have a high level of acquisition of the necessary cognitive competencies taught in their specialization. 
Vol. 10, No. 2, 2021, E-ISSN: 2226-6348 @ 2021 HRMARS

Table 6 also shows the satisfaction levels of the participants on the knowledge of students. As shown in the table, only teacher-participants indicated that they were very satisfied with the students' performance in terms of knowledge. Both school heads and teachers indicated that they were satisfied only with mean ratings of 3.24 and 3.21 , respectively. This means that school heads and teachers both believed that the TVL track has contributed to enhancing the students' leadership skills (Ambag, 2015).

\section{Relationship between Level of Satisfaction and other variables of the study}

An analysis of the relationship between composite adequacy of inputs and composite level of satisfaction positively show a statistically significant relationship between these two variables for the total three samples, for the administrators, teachers, and students. This relationship, significant at 0.000 level, indicates that as the adequacy of inputs increases, the level of satisfaction also increases. When administrators' and teacher's capacity increases, the level of satisfaction also increases. When there are enough school facilities to cater students' needs, the level of satisfaction also increases. The same relationship is evident between curriculum, program objectives, fiscal resources, and linkages. According to Magcalas (2019) sufficient instructional materials are of great importance in the teaching and learning process. These materials along with the effective teaching strategies may help teachers to become more effective and efficient in teaching. These also help the learners to easily understand the lesson teacher want to impart to the learners. According to Escuadro (2018) it is the shared responsibility of the teachers, parents and government to achieve the goals in education. Students will be the one to receive more benefits if this shared responsibility is always present and evident such as improving their academic performance, improving attitudes and behavioral aspects of students.

Table 7. The relationship between level of satisfaction and other variables of the study

LEVEL OF SATISFACTION

\begin{tabular}{lccc}
\hline & $\begin{array}{c}\text { SPEARMAN } \\
\text { RANK } \\
\text { CORRELATION } \\
\text { COEFFICIENT }\end{array}$ & P-VALUE & REMARKS \\
\hline Adequacy of Inputs & 0.478 & 0.000 & REJECT HO \\
Compliance with Standards & 0.627 & 0.000 & REJECT HO \\
Extent of Implementation & 0.769 & 0.000 & REJECT HO \\
\hline
\end{tabular}

A correlation analysis of the relationship between the level of satisfaction and compliance with standards revealed a positive relationship that was significant at 0.000 level. This indicated that as schools increased their compliance there is an increase in the level of satisfaction of the administrators, teachers, and students. A high positive correlations was found between curriculum and instruction and level of satisfaction. This finding indicate that as the DepEd standards on curriculum and instruction are achieved by schools, satisfaction is increased. The same relationship is revealed between human resources and satisfaction. This implies that 
quality assurance in the selection of teachers and staff have significant effect on the level of satisfaction. Environment impacts mood, performance and mental health.

Correlation coefficients obtained for the relationship between level of satisfaction and extent of implementation indicated statistically significant relationship between the factors. Table 7 reveals high correlation coefficient ranging from 0.588 (infrastructure development) to 0.707 (teaching strategies and methodologies). These findings reveal that when there is a high extent of implementation of instruction, teaching strategies, and classroom management, the level of satisfaction is also high. According to Quiroz (2019) teachers should use creative and innovative teaching strategies to meet the students' individual needs and make teaching and learning colorful, fun and enticing.

The findings also reveal that when the implementation of assessment methods is increased, the level of satisfaction also increases. According to Magpoc (2020) assessment has an integral role in teaching-learning because it will help a lot to improve the performance of each student and the school as a whole. It must be enhanced to significantly improve its content and process and to make evaluation and information a part of the teaching-learning process. Finally, satisfaction is increased when school's infrastructure development has high implementation. According to Kapur (2019) when there is a high implementation of infrastructure development the teachers and personnel are able to perform their job duties in a well-organized manner.

\section{Significant difference in the assessment of respondents/participants}

The total computed $\mathrm{H}$ value for adequacy of inputs is 52.490 with a $\mathrm{p}$-value of 0.000 . These results imply that the administrators, teachers, and student of public senior high schools did not have the same perceptions and thoughts about the adequacy of inputs in the Technical Vocational Livelihood program. Apparently, school heads have the highest ratings of evaluation while students have the least mean ratings. Teacher participants stand in the middle. These results imply that students and teachers do not share the same perception with school heads. Teachers and students are the ones who have the opportunity to experience teaching and learning inside the classroom while school heads are more focused on their administrative tasks in managing the school.

The total computed $\mathrm{H}$ value for compliance with standards is 36.885 with a $\mathrm{p}$-value of 0.000 . This means that in terms of compliance there is a statistically significant difference among the responses of school heads, teachers, and students. The null hypothesis is not supported. These results imply that the administrators, teachers, and student of public senior high schools do not have the same perceptions and thoughts about their school's compliance with the DepEd standards in curriculum and instruction, human resources, materials and resources, and work environment. 
INTERNATIONAL JOURNAL OF ACADEMIC RESEARCH IN PROGRESSIVE EDUCATION AND DEVELOPMENT

Vol. 10, No. 2, 2021, E-ISSN: 2226-6348 @ 2021 HRMARS

Table 8. Significant difference in the assessment of group of participants

\begin{tabular}{|c|c|c|c|c|c|c|}
\hline $\begin{array}{l}\text { VARIABLES OF } \\
\text { THE STUDY }\end{array}$ & PARTICIPANTS & MEAN & $\begin{array}{l}\text { MEAN } \\
\text { RANK }\end{array}$ & $\begin{array}{l}\text { KRUSKAL- } \\
\text { WALLIS } \\
\text { TEST } \\
\text { STATISTICS }\end{array}$ & $\begin{array}{c}\text { P } \\
\text { VALUE }\end{array}$ & REMARKS \\
\hline \multirow{3}{*}{$\begin{array}{l}\text { Adequacy of } \\
\text { Inputs }\end{array}$} & School heads & 3.33 & $\begin{array}{c}363.00 \\
\mathrm{~A}\end{array}$ & \multirow{3}{*}{52.490} & \multirow{3}{*}{0.000} & \multirow{3}{*}{$\begin{array}{c}\text { REJECT } \\
\mathrm{HO}\end{array}$} \\
\hline & Teachers & 3.23 & $\begin{array}{c}332.63 \\
\mathrm{~A}\end{array}$ & & & \\
\hline & Students & 2.96 & $\begin{array}{c}234.84 \\
\text { B } \\
\end{array}$ & & & \\
\hline \multirow{3}{*}{$\begin{array}{l}\text { Compliance with } \\
\text { standards }\end{array}$} & School heads & 3.43 & $\begin{array}{c}345.39 \\
\text { A }\end{array}$ & \multirow{3}{*}{36.885} & \multirow{3}{*}{0.000} & \multirow{3}{*}{$\begin{array}{c}\text { REJECT } \\
\mathrm{HO}\end{array}$} \\
\hline & Teachers & 3.37 & $\begin{array}{c}322.49 \\
\mathrm{~A} \\
\end{array}$ & & & \\
\hline & Students & 3.15 & $\begin{array}{c}239.75 \\
\text { B } \\
\end{array}$ & & & \\
\hline \multirow{3}{*}{$\begin{array}{l}\text { Extent of } \\
\text { implementation }\end{array}$} & School heads & 3.48 & $\begin{array}{c}308.42 \\
A\end{array}$ & \multirow{3}{*}{30.377} & \multirow{3}{*}{0.000} & \multirow{3}{*}{$\begin{array}{c}\text { REJECT } \\
\mathrm{HO}\end{array}$} \\
\hline & Teachers & 3.53 & $\begin{array}{c}326.32 \\
\text { A }\end{array}$ & & & \\
\hline & Students & 3.29 & $\begin{array}{c}242.08 \\
\text { B }\end{array}$ & & & \\
\hline \multirow{3}{*}{$\begin{array}{l}\text { Level of } \\
\text { satisfaction }\end{array}$} & School heads & 3.30 & $\begin{array}{c}259.57 \\
A B \\
\end{array}$ & \multirow{3}{*}{13.156} & \multirow{3}{*}{0.001} & \multirow{3}{*}{$\begin{array}{l}\text { REJECT } \\
\mathrm{HO}\end{array}$} \\
\hline & Teachers & 3.44 & $\begin{array}{c}310.15 \\
A\end{array}$ & & & \\
\hline & Students & 3.25 & $\begin{array}{c}251.90 \\
\text { B }\end{array}$ & & & \\
\hline
\end{tabular}

\section{Mean ranks followed by a Common Letter are not Significant at $\mathbf{5 \%}$ level}

The total computed $\mathrm{H}$ value for Extent of implementation of processes is 30.377 with a $\mathrm{p}$ value of 0.000 . This result implies that except for curriculum understanding and instruction the administrators, teachers, and student of public senior high schools did not have the same perceptions and thoughts about their school's extent of implementation of the TVL program as to teaching strategies and methodologies, classroom management, assessment and evaluation, and infrastructure development. The school heads and teachers both have an apparently higher mean ranks as compared to that of students. This may be attributed to the fact the administrators and teachers are more concerned with the totality of the extent of implementation of the program whereas students are more concerned only with what they experience inside the classroom. According to Salandanan (2017) administrators and teachers, as the backbone of the institution, they are responsible for the academic environment that each student under their 
care receives. They set the tone of the school. They decide on staffing decisions. There are many effective administrators at the helm of schools. To Encio (2017) for school heads, it is more than a requirement to master the curriculum, formulate good evaluation tools and research for them to provide the necessary assistance and control mechanism to teachers and students in all aspects of school development.

The total computed $\mathrm{H}$ value for compliance with standards is 13.156 with a $\mathrm{p}$-value of 0.0001 . These results imply that the administrators, teachers, and student of public senior high schools did not have the same level of satisfaction on the performance of students as output of the TVL program. Evidently, teachers have the highest mean rank of 310.15 among the three groups. It can be attributed to the fact that teachers are the ones who make the actual assessments of the knowledge, skills and attitudes of the students. Compared to school heads, teachers are able to make actual observations on the students. They are also the ones who conduct assessment and evaluation of student performance and outputs. According to Magpoc (2020) the role of teachers in testing or in assessment procedure of learners is very important to be taken for granted. Educators everywhere agree in saying that classroom teachers should have a high level of competence in evaluation, especially in classroom assessment. With the present type of evaluation being done in schools today, teachers really need to be more updated with the times. Such area of concern must be prioritized by all mentors alongside with teaching methodologies and strategies in different learning areas.

\section{Problems encountered in the implementation of the TVL track}

Selected school heads, TVL teachers, and students were interviewed on the problems met in the implementation of the TVL track. Their responses were coded to form themes. As revealed in the interviews, the following are the most prevalent problems they encounter in the implementation of the TVL track.
a. Limited financial resources
b. Inadequacy of tools, materials, and equipment
c. Lack of relevant work immersion partners
d. Inadequacy of safe and secure sanitary facilities including provision of safe drinking water
e. Too many administrative work burdens teachers
f. Lack of other specializations which are relevant to the needs of the community

\section{Conclusions}

The results show that the school heads and teachers ensure that the delivery of techvoc instruction is in accordance with the standards set by the department. A high extent of implementation is a manifestation of good classroom processes that results to good student performance.

The level of satisfaction is significantly correlated with the adequacy of inputs, compliance with standards, and extent of implementation. This implies that adequacy have an effect on the satisfaction. When there is more than enough input like tools, materials, and equipment, teachers and students become highly satisfied with the program. It can be inferred that teachers and students are more satisfied with the TVL track when there is high compliance by the schools. 
Vol. 10, No. 2, 2021, E-ISSN: 2226-6348 @ 2021 HRMARS

This implies that if there is a good implementation of the teaching and learning, the more that students and teachers are satisfied with the TVL track.

\section{Recommendations}

Schools may enhance the level of TVL implementation by offering more relevant specializations, providing enriched classroom experience through symposia and workshops, and by establishing a computer facility for student research.

Schools may set a framework for the delivery of techvoc instruction to adapt the challenges brought by the so called "New Normal".

Further researches of the same nature but involving employability of the TVET students/graduates may be conducted. Also, future researches involving a tracer study of the graduates of TVL track may be conducted.

\section{References}

Ambag, S. (2015). Technical Vocational Education in the Eye of Professionals. . Retrieved from https://www.researchgate.net/publication/322386172.

Agrawal, T. (2013). Vocational education and training programs (VET): an Asian perspective., . Asia-Pacific Journal of Cooperative Education, 14(1), 15-26.

Albarico, S. E. (2014). Adequacy of Instructional Materials Used by Teachers in Teaching Technology and Livelihood Education. Retrieved from http://icehm.org/upload/6031ED0114516.pdf.

Alferez, R. C., \& Palmes, N. D. (2012 ). Implementation of Strengthened Technical Vocational Education Program- Competency Based Curriculum, Northern Mindanao, Philippines. JPAIR Multidisciplinary Journal Vol. 7.

Audu, R., Sukri, M., \& Musta'amal, A. (2013). Provision of Workshop Tools and Equipment: Necessity for Technical Vocational Education Graduates Skills Acquisitio . 2nd International Seminar on Quality and Affordable Educaiton .

Brillantes, K. D., Orbeta, A., Abrigo, K., Capones, E., \& Jovellanos, J. B. (2019). Status of Senior High School Implementation: A Process Evaluation.

Castillo, R. (2012). "Arts and Trade Program Enhancement in Bauan Technical High School". Unpublished Master's Thesis, Batangas State University, Batangas City.

Cedefop. (2012). Thematic Overview for Finland, Practices to Math VET Provision with Skill Needs.

Chae, C., \& Chung, J. (2009). "Pre-Employment VET in Korea in Social Protection and Labour,". Discussion Paper No 0921, World Bank.

Click, P. (2000). Administration of Schools. USA: Delmar Thomson Learning Pub, Inc.

Cohen, L., Manion, L., \& Morrison, K. (2007). Research Methods in Education 6th Edition. New York: Routledge 2 Park Square,Milton Park,Abingdon,OxonOX14 4RN.

Constant, L., Culbertson, J., Luoto, J., \& Vernez, G. (2012). Employer Demand for Technical and Vocational Skills in the Kurdistan Region-Iraq.

DepEd Order No. 21, s. 2. (2019). Policy Guidelines on the K to 12 Basic Education Program. Retrieved from http://www.deped.gov.ph 
Edmond, A. (2016). Assessment of the Adequacy of Material Resources for Effective Teaching of Building Technology: A Panacea for Promoting Entrepreneurial Skills in Rivers State Technical Colleges. Retrieved from http://eajournals.org/wpcontent/uploads/Assessment-of-the-Adequacy-of-Material-Resources-FOR-EffectiveTeaching-of-Building-Technology.pdf.

Esguerra, E., \& Orbeta, A. (2016). The National System of Technical Vocational Education and Training in the Philippines: Review and Reform Ideas. Discussion Paper Series No. 201607. Philippine Institute for Development Studies.

Gregorio, M. (2016). Technology and Livelihood (TLE) Instruction of Technical Vocational and Selected General Secondary Schools in Catanduanes. International Journal of Learning, Teaching and Educational Research Vol. 15, No.4, 69-74.

Ike, H., Nwamuo, C., \& Ojukwu, U. (2011). Provision of Technical Vocational Training in Formal Education for Sustainable Technology Development. Nigeria. Journal of Nigerian Association of Teachers of Technology,7(3), , 54.

Jaminal, B. D. (2019). The Impact of School Facilities to the Teaching-Learning Environment. SMCC Higher Education Research Journal Vol. 6.

Kong, J. I. (2017). Level of Awareness, Preparedness and Readiness of the Technical-Vocational Institutions in the Implementation of the $\mathrm{K}$ to 12 Curricukum in Zamboanga Peninsula. JPAIR Institutional Research Vol. 10.

Leong, P. (2011). Key Reforms in Revitalising Technical and Vocational Education and Training (TVET) in Malaysia. egional Conference on Human Resource Development Through TVET as a Development Strategy in Asia. Sri Lanka: Retrieved on May 5, 2016 from https://goo.gl/spBzX4.

Limon, M. (2016). The Effect of the Adequacy of School Facilites on Student's Performance and Achievement in Technology and Livelihood Education. International Journal of Academic Research in Progressive Education and Development Vol. 5, No.1.

Naelga, S., \& Blane, A. (2017). Identification of the Technical Vocational Track Strands to Be Implemented For Senior High School at the District of Claveria-2, Claveria,. Mindanao University of Science and Technology.

Okorie, J. (2000). Developing Nigeria's Workforce. Calabar. Page Environ publisher.

Olabiyi, O. S., Adigun, E. O., \& Adenle, S. O. (2008). Assessment of the Adequacy of Training Facilities Used for Vocational and Technical Education in Colleges of Education in South West Nigeria. African Journal for the Study of Educational Issues: 4 (3), , 44-52.

Omekwe, I. (2009). Issues and Problems in the Implementation of Vocational Education Programs in Nigeria. Ilesha: Joja Educational Research Publishers.

Osuala, E. (2004). Foundations of Vocational Education. Nsukka: Cheston Books.

Perez, R. (2018). Becoming Successful K to 12 Implementers: Operational Preparedness of Senior High Schools in Hagonoy, Bulacan, Philippines. JPAIR Multidisciplinary Research Journal.

Sabit, L. A. (2019) ). The Status of School Facilities for Special Program in the Arts (SPA): Its Influence on the Student Performance. SMCC Teacher Education Journal Vol. 1.

Salam, A. (2015). Input, Process and Output: system approach in education to assure the quality and excellence in Performance. Bangladesh Journal of Medical Science Vol. 14 No. 1. 
INTERNATIONAL JOURNAL OF ACADEMIC RESEARCH IN PROGRESSIVE EDUCATION AND

DEVELOPMENT

Vol. 10, No. 2, 2021, E-ISSN: 2226-6348 @ 2021 HRMARS

Salatan, J. (2018). Status of Selected Secondary Schools in the Implementation of Technology and Livelihood Education Program. Retrieved from http://www.ijlter.org/index.php/ijlter/article/viewFile/671/290.

Salleh, K., \& Sulaiman, N. (2015). Technical Skills Evaluation Based on Competency Model for Human Resources Development in Technical and Vocational Education. Asian Social Science, 11(16), 74.

Serumu, I. (2014). Challenges of Implementing Technical and Vocational Education and Training Curriculum in Nigerian Universities. Global Advanced Research Journal of Educational Research and Review Vol. 3(5), pp. 098-101.

Tullao, T. S. (2003). Education and Globalization. Makati City : Philippine APEC Study Center Network (PASCN).

Yusof, H., Noor, M., Jalil, N., Mansor, M., \& Nordin, J. (2019). Teachers' Perception of Students' Knowledge, Skills, and Attitudes on Global Citizenship. International Journal of Academic Research Vol. 9 No. 9, 153-164. 